\title{
Integration of CITYgreen Landscape Ecological Analysis into A Capstone Environmental Science Course
}

\author{
David L. Kulhavy ${ }^{1}$, Daniel R. Unger ${ }^{2}$, Reid Viegut ${ }^{3}$, I-Kuai Hung ${ }^{4} \&$ Yanli Zhang ${ }^{5}$ \\ ${ }^{1}$ Laurence C. Walker Distinguished Professor, Arthur Temple College of Forestry and Agriculture, Stephen F. \\ Austin State University, USA \\ ${ }^{2}$ Robert Minton Distinguished Professor, Arthur Temple College of Forestry and Agriculture, Stephen F. Austin \\ State University, Nacogdoches, Texas, USA \\ 3 Research Assistant, Arthur Temple College of Forestry and Agriculture, Stephen F. Austin State University, \\ Nacogdoches, Texas, USA \\ ${ }^{4}$ Lacy Hunt Professor, Arthur Temple College of Forestry and Agriculture, Stephen F. Austin State University, \\ Nacogdoches, Texas, USA \\ ${ }^{5}$ Professor, Arthur Temple College of Forestry and Agriculture, Stephen F. Austin State University, Nacogdoches, \\ Texas, USA \\ Correspondence: David L. Kulhavy, Laurence C. Walker Distinguished Professor, Arthur Temple College of \\ Forestry and Agriculture, Stephen F. Austin State University, USA
}

Received: August 10, 2020

doi:10.5430/ijhe.v9n6p259
Accepted: September 21, $2020 \quad$ Online Published: September 30, 2020 URL: https://doi.org/10.5430/ijhe.v9n6p259

\begin{abstract}
CITYgreen Geographic Information Systems software was used to develop a campus wide cover type map for Stephen F. Austin State University in an environmental science landscape ecology course. The finding indicated an equal division of forest cover type compared to impervious surface of buildings and paved surface. Once the classification was completed, students chose an area for reforestation identified in CITYgreen, while raising funds for the purchase of trees for the project. Before completing the project, students reviewed tenets of landscape ecology, civic ecology education, and benefits of urban forestry. At the completion of the project, students reviewed service-learning aspects of campus beautification reflecting on making a difference, working outdoors, and using high end technology to complete a real-world environmental project incorporating partnerships and teamwork. The outcome demonstrates the benefits of applying ecological planning to complete an environmental project based on a perceived need within a campus setting.
\end{abstract}

Keywords: university, conservation, natural resources, civic ecology education, landscape ecology

\section{Introduction}

Environmental science undergraduate education within the Arthur Temple College of Forestry and Agriculture at Stephen F. Austin State University (SFA) places an emphasis on working outdoors while using high end technology to make a difference in understanding the breadth and depth of knowledge to address the complex environmental challenges in modern society (Bullard et al., 2014). Within the Land and Water Resources track, courses in Geographic Information Systems (GIS) in Natural Resources, Landscape Ecology, and Ecological Planning, are combined as techniques to both visualize and measure the environment for spatial analysis. To make environmental and management decisions, CITYgreen planning tools can be used for future uses of the landscape. CITYgreen GIS applications estimate the impact of the forest and trees in removing air pollution and lessening the impact of storm water runoff (Byrne \& Jinjun, 2009) and measuring forest and field cover types (Longcore, Li \&Wilson, 2004). These applications can be implemented over a landscape scale to produce data analysis of environment concern for a geographically defined area (Coulson and Tchakerian, 2010).

Within the campus urban forest, emphasis is placed on utilization of the trees and landscape to estimate reduction of pollution and runoff. The Stephen F. Austin State University campus forest and trees are managed by the SFA Gardens (68 acres) with the remainder (331 acres) managed by an arborist with the tree canopy as an arboretum and a managed forest. This designation includes tree distribution and hazard rating the health and environmental impact of the overstory forest (Kulhavy, Wu, Unger, Hung, \& Sun, 2014). The remainder of campus contains a mix of 
overstory forest, buildings, open space, roads and parking lots and trails. To assess the forest overstory, Unmanned Aerial Systems (UAS) were used to compare the visual assessment of the health of the forest to the use of the standard CTLA (Council of Tree and Landscape Appraisers) method, resulting in no statistical difference between the two systems (Kulhavy, Unger, Hung, \& Zhang, 2016). Assessing urban forest cover type includes evaluating the physical aesthetic and environmental benefits related to ecological contributions of the urban forest (Kulhavy, Wu, Unger, Hung \& Sun, 2014). Continued assessment includes monitoring species composition, size of the urban forest, and evaluation for economic and aesthetic benefits (McPherson et al., 1997).

As students became familiar with the methodology of CITYgreen, they were tasked with creating an overlay of campus. Once this was completed, tenets of landscape ecology were discussed based on the patch, corridor matrix model (Forman, 1995; Coulson and Tchakerian, 2010) to explore options for directing change of vegetation on a college campus. Methods of change needed to be directed by planned activities (i.e., tree planting) based on campus groups working together to increase greening of the campus or repair of desire trails (Krasney and Tidball, 2012; Kulhavy, Unger \& Hung, 2018). Once these were completed, students presented their findings in a group-led service-learning project integrating planning with spatial change based on principles of landscape ecology to promote campus change (Kulhavy \& Unger, 2016)

\section{Literature Review}

\subsection{CITYgreen}

CITYgreen is a planning tool for regional, local and landscape-watershed analysis of environmental function and economic value of urban trees and forests (Burns, 2007). Ecological parameters for CITYgreen include stormwater runoff, carbon sequestration and air pollution removal potential. CITYgreen was developed by American Forests to calculate benefits of urban forests and urban greenspace (Longcore, Li \&Wilson, 2004). CITYgreen uses GIS software for mapping, measuring and analyzing urban ecosystems as an extension of ESRI's ArcGIS software. The mission of American Forests is to advance the conservation of forests and to promote and expand urban forests. Community-based initiatives work with people to plan and implement healthy ecosystems and communities.

CITYgreen with Sanborn Green Infrastructure Mapping uses high resolution multispectral imagery with an area of interest to create landcover datasets for a community or organization. This promotes planning for green infrastructure, canopy analysis, and measurement of impervious areas for stormwater and drainage management for land management applications (Sanborn, 2014). Barnett et al. (2010, 2011) developed an education program, the Urban Tree Project, for secondary education for environmental science urban ecology and environmental technology programs; and completed a CITYgreen project for energy savings, air quality and storm water runoff for a Boston public high school. The use of CITYgreen led to improving science self-efficacy, knowledge of the ecosystem and appreciation of the urban ecosystem (Barnett et al., 2006, 2011).

The CITYgreen project work supports urban environmental education to encourage awareness, knowledge, attitude formation, skill development, and participation in solving environmental problems (Frank \& Zamm,1994; Tidball \& Krasny, 2010). This increases the understanding of ecosystem structure, function, and change (Tidball and Krasny, 2010; Coulson and Tchakerian, 2010) and the development of civic ecology education. Longcore, Li \& Wilson (2004) evaluated CITYgreen for dense neighborhoods as a method of evaluating increasing greenspace. CITYgreen estimated energy savings more accurately in highly vegetated, more established neighborhoods (Carver, Unger \& Parks, 2004). CITYgreen software estimated savings from urban forests in Shenyang, China for 19,944 trees values at $\$ 16,318.21 /$ year. In Washington, DC, existing 46 percent canopy could reduce the need for retention structures by $\$ 4.7$ billion over a 20-year period (Jim \& Chen, 2009).

\subsection{Integration with Landscape Ecology}

'Landscape ecology' is defined as the science that defines the ecology of a landscape in a spatially explicit area (Coulson \& Tchakerian, 2010). Landscapes are characterized by heterogeneity with the composition of different kinds of spatially defined ecosystems. These landscapes are arranged in a mosaic with patterns and processes that shape the structure, function, and change of the area. The scale and temporal events in a landscape are variable resulting from an exchange of energy, materials, and information within and among the existing ecosystems (Coulson \& Tchakerian, 2010). Within Landscape Ecology, 'ecology' is the study of organisms interacting in the environment (Campbell \& Reese, 2005), affecting change in the landscape.

\subsection{Civic Ecology Education}

Civic ecology education links urban areas to social-ecological issues to focus on urban social-ecological issues. Incorporation of reflection of stewardship practice, science learning, and communication skills are essential to this 
process (Krasny \& Tidball, 2009, 2010; Tidball \& Krasny, 2007). The inclusion of educational programs and stewardship practice increase the greater caring for the social-ecological issues in the structure and function of the urban forest (Tidball \& Krasny, 2010). The decision to plant or restore an urban forest community leads to changes in land use and ecological processes and conditions that resulted in expanded recreational and cultural connections, sense of place, and an ability to care for the urban forest. The planting and renewal of the forest add to the urban canopy increasing the education and cultural activities and support of an urban forestry sustainability plan.

The embracing of civic ecology education incorporates anthropogenic change in a landscape resulting in measurable impacts on communities and ecosystems where they reside (Tidball \& Krasny, 2010). Community enhancement and restoration occur and are enhanced by connections and understanding of ecological processes (Krasny \&Tidball, 2009). Civic ecology education leads to partnerships and teamwork to restore and maintain urban ecological communities to create a sense of place (Krasney \& Tidwell, 2012). Shirk et al. (2012) stress the need for public participation in scientific research (PPSR) to increase cooperation in solving both environmental and social projects.

\subsection{Benefits of Urban Forestry}

The urban forest provides ecosystem benefits to the university or community and can be incorporated as part of the planning process. Landcover classifications for American Forest Products include two levels of classification. Level 1 classification includes Non-woody Vegetation divided into Level 2, Grassland, Cropland, and Urban Grassland; Level 1, Woody Vegetation, divided into Level 2 Tree and Shrub; Level 1, Impervious, Water and Bare Soil (Sanborn, 2014). Urban forests include urban forest cover, forest health and ecosystem services benefits contributing to local climate and energy use, air quality, climate change, water flow and soil quality, land value, and individual and community well-being (Chen \& Jim, 2007; Nowak et al., 2010).

Tree canopy cover in Nacogdoches County is between 30 and 50 percent with 5,000 to 10,000 square foot per person and an Urban Tree Canopy Index of 0.81 to 1.00 , indicating the greatest relative cover (and benefits) compared to similar counties in the region (Nowak et al., 2010). The knowledge of urban community forestry is integral to understanding urban natural resources management. Urban forests are important to protect and manage as they add benefits to the landscape; they can be managed in partnerships; and knowledge of structure, function and intended change can assist in allocating resources to improve the forest (McPherson et al., 1997). To effectively manage the urban forest, it is essential to know the location of the forest in relation to existing buildings and roadways (Nowak, 1994).

Urban greenspace benefits our cities that requires the development of guidelines for urban forest management. CITYgreen can be used to model ecological services for savings based on carbon sequestration, stormwater runoff and confinement, dust suppression, and access to nature. Carbon sequestration is the amount of carbon sequestered by the urban forest each year based on tree growth with subtraction for tree loss. Stored carbon is based on the size of the trees at the time of measurement (Rowntree \& Nowak, 1991). Perceived disadvantages are storm damage of trees, nuisance wildlife, and less public safety (Byrne \& Junjun, 2009).

\section{Methods}

\subsection{Study Area}

The study area is the campus of Stephen F. Austin State University, Nacogdoches, Texas covering 389.4 acres (Figure 1). The campus is characterized by forests, fields, buildings, water, and impervious surface. For CITYgreen, the areas were divided into Impervious Surface/buildings, structures; Impervious Surface/paved, drains, sewers; Impervious Surface/unpaved soil; Open Space/grass > 75 percent cover, scattered trees; Open Space/grass 50-75 percent cover, scattered trees; Trees: Forest litter understory/ covers soil; Tress: grass/turf understory covers 50-75 percent. Layers of building, road corridor, parking lot, water and bare soil were created to estimate the Impervious layers. To calculate the Trees layer and Open Area, an aerial image was created for measurement of the area.

\subsection{Integration into Landscape Ecology}

Students digitized the areas of campus based on the categories developed for CITYgreen. Themes were selected from the CITYgreen menu and entered into a queue for planning the digitized area of the campus based on the patch, corridor, matrix model of landscape ecology as a part of landscape planning. Once the maps were completed, students planned an environmental project following discussion of civic ecology education and use of the images from CITYgreen. Following their project idea, they carried out the project and met for service-learning discussion based on public participation projects. This resulted in a greening of the campus as part of integration of the constructs of landscape ecology, civic ecology education, and service-learning tenets. 


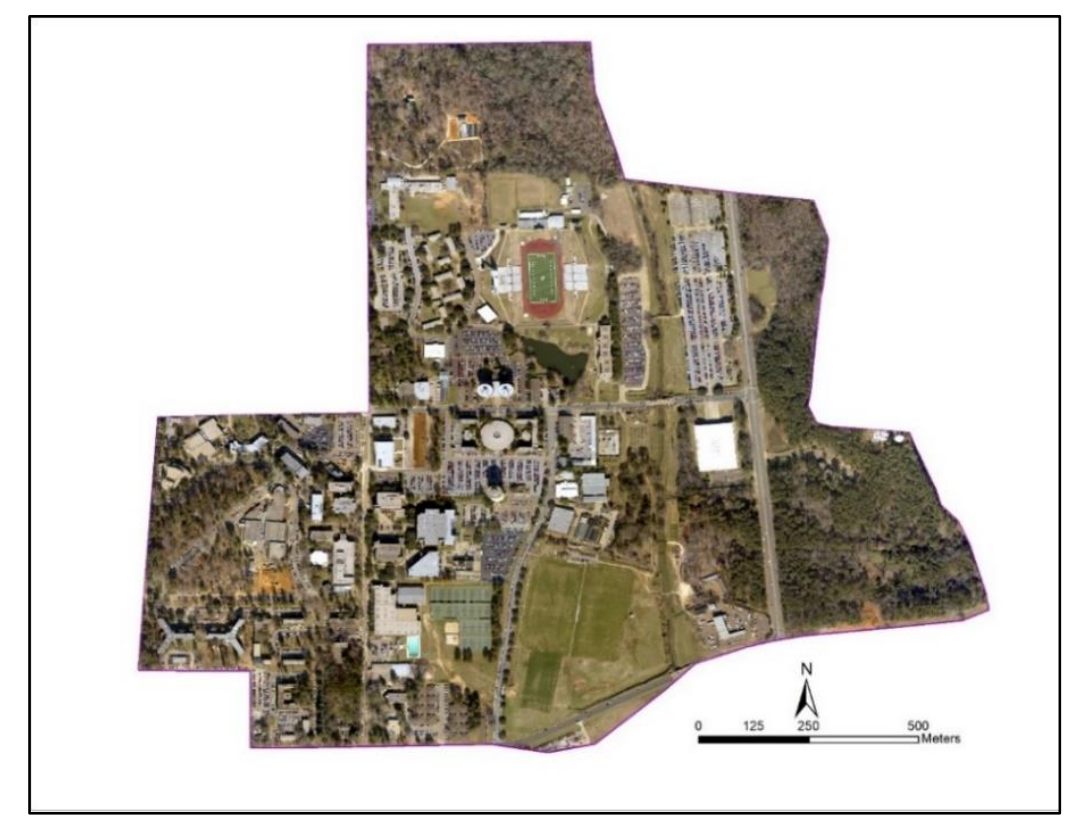

Figure 1. Campus of Stephen F. Austin State University, Nacogdoches, Texas

\section{Results}

For calculation of the largest area, the Tree Canopy covered 133.9 acres (34.4 percent of the campus area) with 125.4 acres ( 32.2 percent) in the canopy covering the soil; and 8.6 acres ( 2.2 percent) covering $50-75$ percent of the ground (Figure 2). Open Space covered 120.1 acres (30.9 percent) with grass covering 50-75 percent, 85.6 acres (22.0 percent); and grass $>75$ percent, 34.5 acres ( 8.9 percent) (Figure 1). Impervious Surfaces covered 135.4 acres (34.8 percent) with buildings and structure 51.8 acres (13.3 percent); paved, drain to sewer, 67.6 acres (17.4 percent); and unpaved soil, 16.0 acres $(4.1 \%)$. Imperious areas of buildings, parking lots, bare ground, and water are presented in Figure 3.

For the campus, the Tree Canopy and Grass covers were primarily in the undeveloped areas (Figure 4). In the northern area is the 40 acre Piney Woods Native Plant Center (PNPC), an area dedicated to conservation education with the Ina Brundrett Conservation Education center, a 1,500 square foot building with a classroom, and a specimen preparation and storage area. The building has solar panels that supply 80 percent of the energy. Next to the Brundrett center is the Tucker House, a fully functioning area for conservation education and horticulture. Over 13,000 youth come to the area annually for conservation education programs. The PNPC is both a formal garden and an extension of Ladybird Johnson Wildflower Center. A 5,000 square foot greenhouse and horticulture trial area serves as a teaching and research center. The forty acres contains kiwifruit trials, grape arbors, and bald cypress cultivars.

In developing planning for an environmental resource projects, areas of campus were examined based on the results of CITYgreen for areas of restoration or campus beautification. The 75 acres on the eastern portion of the university contains Hunt's Woods, Surveyor's Hill as set aside areas; and the formal Gayla Mize Friendship Garden. The area is largely undeveloped with hiking trails, bike trails, and areas for forestry education including forest measurements, introduction to forestry, surveying, tree identification, forest ecology, and forest insects and diseases. An area for group activities for both a high and low ropes course and challenge wall is in the forest. Management is kept at a minimum due to the high erosion potential of the soil

The area at the main entrance to the campus is termed Vista Woods and at present is an area for urban forestry, environmental education, and forest restoration using civic ecology education for group participation. This area connects to the residence halls with extended tree cover. Next to La Nana Creek on the east area of campus is a series of formal gardens, including the Ruby Mize Azalea Garden, the A. T. and Pat Mast Arboretum, and the Kingham Children's Garden that are under the Tree Canopy cover. Within the main part of the campus around. 


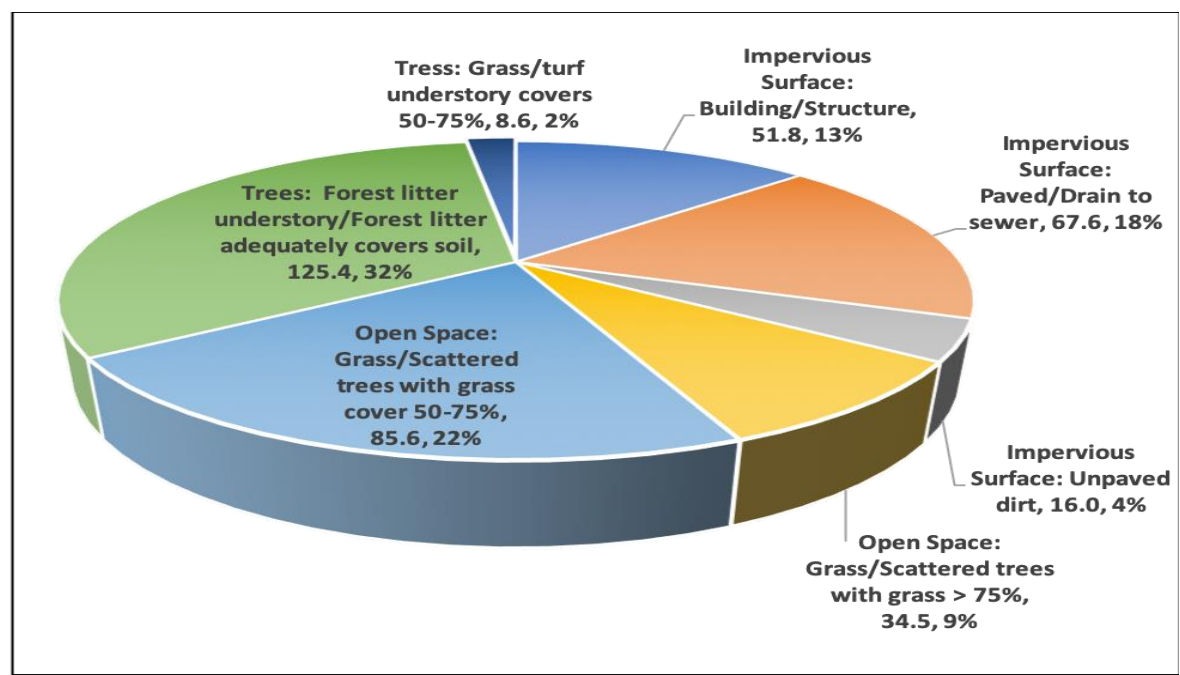

Figure 2. Acreage and percent of cover for Stephen F. Austin State University

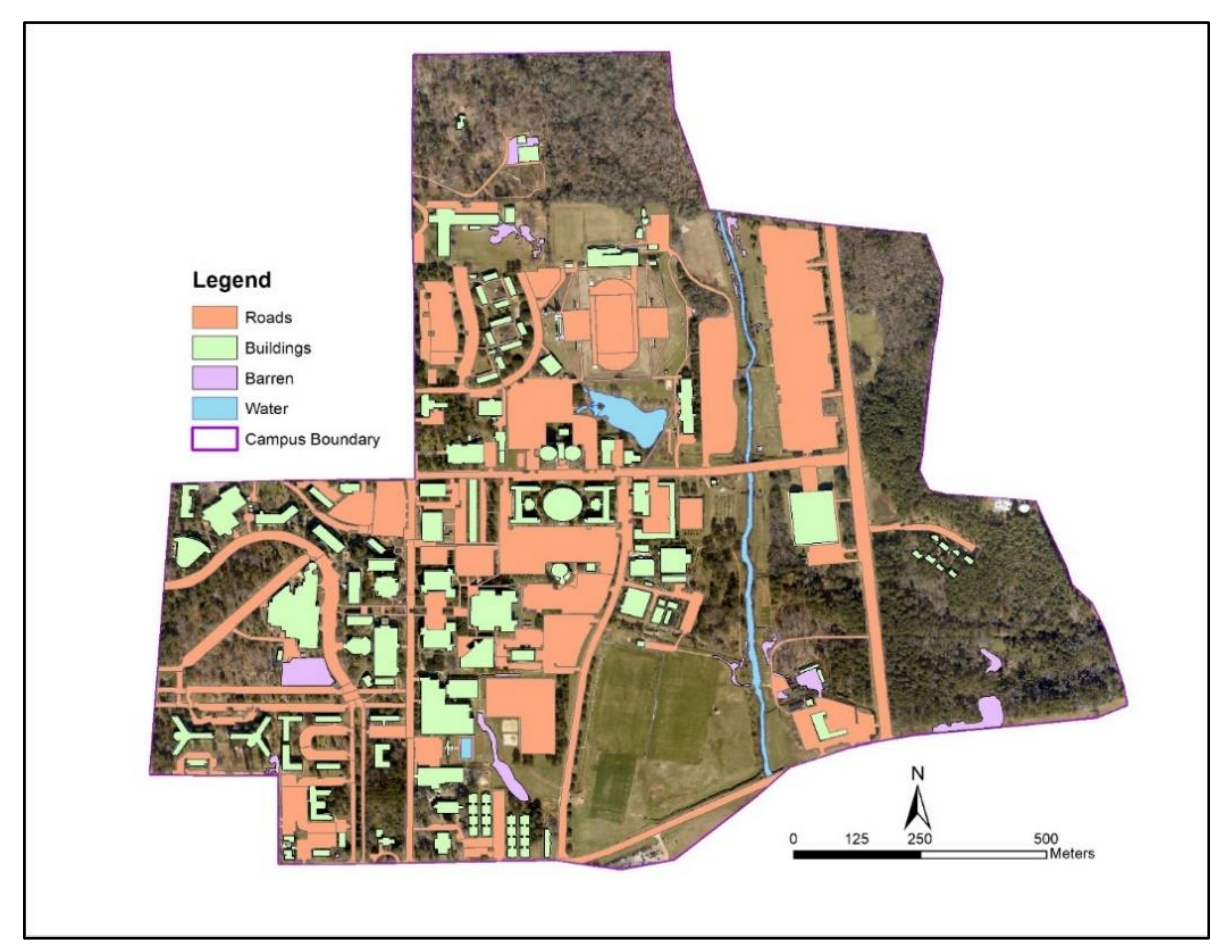

Figure 3. Impervious surface layers based on roads and parking lots, buildings, barren ground and water 


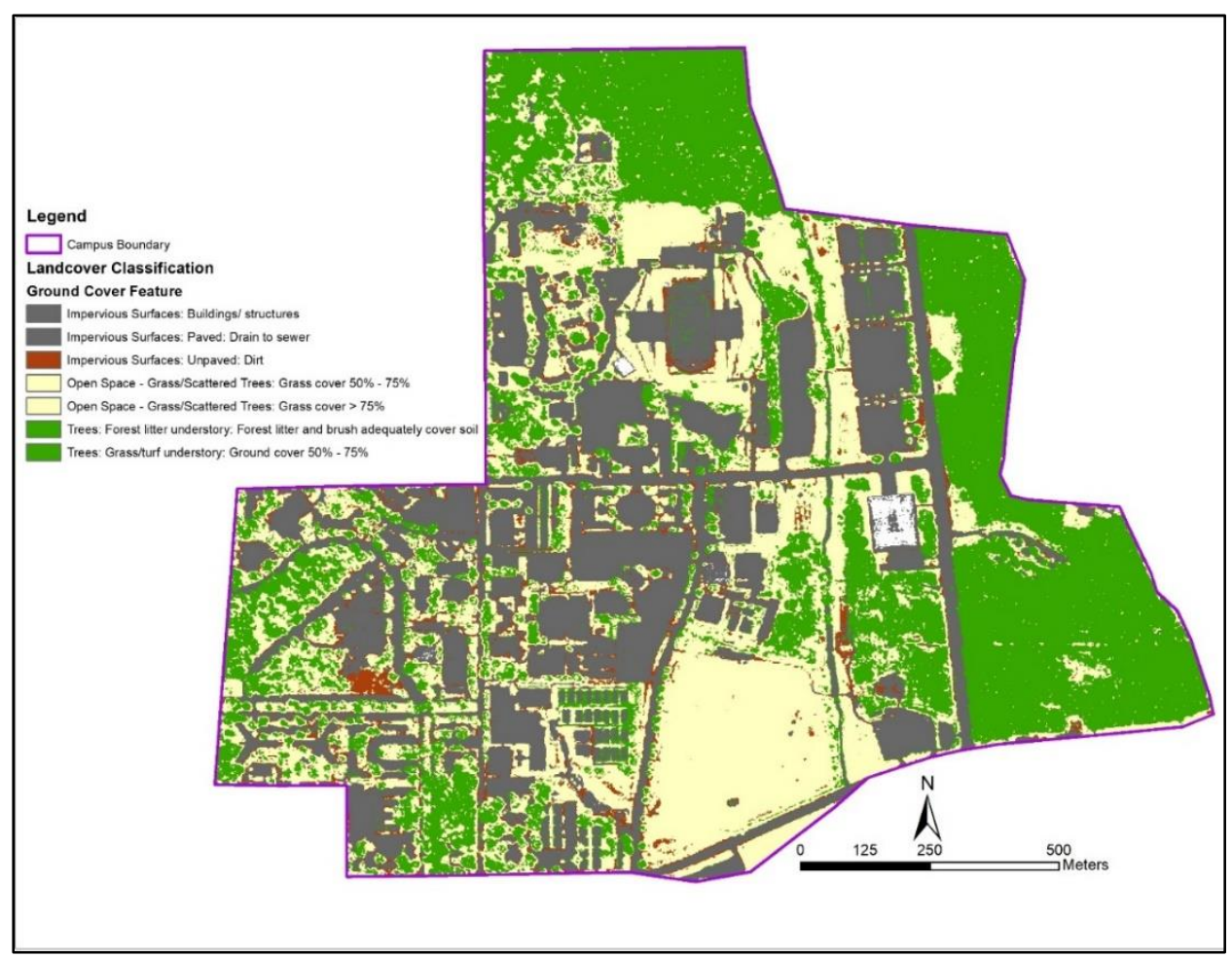

Figure 4. CITYgreen cover on Stephen F. Austin State Univesity Campus combining Impervious Surface, Open Space and Trees with Forest Litter and and Grass Understory

academic buildings and residence halls are forests maintained by a campus arborist to enhance the protection and health of the urban forest. This use of the Tree Canopy area is tied to both teaching and service for the university and the community. The forest canopy protects a hiking trail along the La Nana Creek that is important to community health and as the historic Ghosts of Nacogdoches Trail. Impervious areas are divided into parking lots, buildings and road surfaces. These areas contribute to the increase of the stormwater runoff from the university into the La Nana Creek or the surrounding area. The areas of impervious surface are concentrated in the center of campus with outliers in parking lots and roads. As building and parking garage construction increases, increased emphasis needs to be placed on water run-off and storm water effluent. Bare ground areas are either areas of erosion along La Nana Creek or new construction near the Baker Pattillo Student Center.

Open space areas include a recreation complex termed the Intramural Field, essential for outdoor activities and recreation. Additional areas include the football stadium complex and track and field practice centers tied to increase physical activity in the environment. Areas along La Nana Creek are set aside for runoff and needed areas to meet standards of the creek as mandated by state and federal standards. Within the forested areas are scattered open areas created where crown canopy is less than 50 percent of coverage. These areas are available for additional planting to increase the species diversity on campus and enhance the increase of the tree canopy.

Air pollution removal was an estimate of removal of carbon monoxide, ozone, nitrogen dioxide, particulate matter and sulfur dioxide. A total of 15,999 pounds were removed per year with particulate matter the highest $(5,612$ pounds) and carbon monoxide the lowest (478 pounds). For dollar value per year, ozone was the highest $(\$ 18,983)$; and particulate matter the lowest (\$234) (Table 1). For carbon storage and sequestration, a total of 5,763 tons were stored; and 45 tons sequestered annually using the carbon and storage model of Nowak and Crane (2002). Annual gross carbon storage by urban trees in the USA is 600 to 900 tons (Nowak, 1994), with 15,900 million tons in the non-urban landscape. In Monetary value of urban forest annual carbon sequestration is 22.8 million tons per year with a value of $\$ 460$ million; and $\$ 14,300$ million for carbon storage. 
Table 1. Volatiles and carbon sequestration for the campus area

\begin{tabular}{lll}
\hline & Lbs. Removed/Year & Dollar Value/Year \\
\hline Carbon Monoxide & 478 & $\$ 234$ \\
Ozone & 5,373 & $\$ 18,983$ \\
Nitrogen Dioxide & 2,388 & $\$ 8,437$ \\
Particulate Matter & 5,612 & $\$ 13,237$ \\
Sulfur Dioxide & 2,149 & $\$ 1,855$ \\
Totals & 15,999 & $\$ 42,746$ \\
\hline
\end{tabular}

\section{Discussion}

Once the campus was mosaicked using CITYgreen, an area was selected in discussion with student groups on an environmental restoration project. The project selected was tree planted in the scattered forest of Vista Woods at the main entrance to the campus. CITYgreen provides guidelines for tree canopy, open space, impervious areas bare ground to evaluate green space, use of the area and continued evaluation into the future landscape analysis. As buildings are constructed, CITYgreen can be updated to measure impervious area and plan for increased stormwater runoff. Guidelines from CITYgreen can be utilized to plan urban forest management of the campus. The combination of canopy tree cover, formal gardens, and enhanced recreation areas add to the ambience of the campus by providing areas for sense of place, relaxation, and outdoor learning.

Once the CITYgreen project was completed, forestry and environmental science students organized a tree planting program following training in service-learning and using the practice of civic ecology (Krasney and Tidwell, 2012). Over 400 trees were planted in a reforestation program in the open areas identified by CITYgreen. The main area planted was the green-set aside area at the main entrance of the university. Students met with Buildings and Grounds and the SFA Gardens to connect for planting tools, mulch, and tables for registration. Methods of planting were demonstrated and a trained planter went with each crew. The project was funded by student government for purchase of the trees. The university supplied mulch and the SFA Gardens and Forests advised on tree selection and planting areas. The pre-planning and positioning of materials led to the completion of the project in a single day. Students were trained in service-learning (Kulhavy et al., 2017) taking time for reflection on completion of the planting project. Each tree was located with a GPS unit and entered into the university database maintained by the Arthur Temple College of Forestry and Agriculture.

\section{Conclusions}

Within the environmental science, forestry, and spatial science programs, students are encouraged to work outdoors, use high end technology, and to make a difference in the campus and professional community (Bullard, Stephens Williams, Coble, Coble, Darville, \& Rogers, 2014). Guidelines presented by results of CITYgreen point to a trajectory of management to leave tree canopy and open space for future management. The reduction of stormwater runoff and organic volatiles enhance the long-term sustainability of the campus. The Ina Brundrett Conservation Education Building at the PNPC provides a focal point for environmental management. Integrating urban forest management with civic ecology education and the tenets of landscape ecology increases the understanding of the importance of tree canopy and preservation of the urban forest. This process demonstrated the integration of knowledge students learned in forestry, environmental science, and spatial science that was applied to a real-world project. In return, it benefits the university and the community.

\section{Acknowledgements}

This project was completed using McIntire-Stennis funds administered by the Arthur Temple of Forestry and Agriculture, Stephen F. Austin State University.

\section{References}

Barnett, M., C., Lord, C., Strauss, E., Rosca, C., Langford, H., Chavez, D., \& Deni, L. (2006). Using the urnan environment to engage youths in urban ecology field studies. The Journal of Environmental Education, 37, 3-11. https://doi.org/10.3200/JOEE.37.2.3-11

Barnett, M., Houle, M., Hufnagel, E., Pancic, A. Lehman, M., \& Hoffman, E. (2010). The Urban tree project, using geographic information systems to determine the ecological value of neighborhood trees. The Science Teacher, $77,32-35$. 
Barnett, M., M. Houle, M., Vaughn, E. Strauss, E., \& L. Cotter, L. (2011). Urban environmental education: leveraging technology and ecology to engage students in studying the environment. International Research in Geographical and Environmental Education, 20, 199-214. https://doi.org/10.1080/10382046.2011.588501

Bullard, S. H., Stephens Williams, P., Coble, T., Coble, D. W., Darville, R., \& Rogers, L. (2014). Producing "society-ready" foresters: A research-based process to revise the Bachelor of Science in Forestry curriculum at Stephen F. Austin State University. Journal of Forestry, 112(4), 354-360. https://doi.org/10.5849/jof.13-098

Burns, D. (2007). Land use Planning with CITYgreen. Land Bulletin of the National Consortium for Rural Geospatial Innovations. RGIS Cheapeake, Wilkes University, Wilkes-Barre, PA.

Byrne, J., \& Jinjun, Y. (2009). Can urban greenspace combat climate change: Towards a subtropical cities research agenda. Australian Planner, 46, 36-43. https://doi.org/10.1080/07293682.2009.10753420

Campbell, N., \& Reese, J. (2005). Biology. Benjamin-Cummings Publishing Company, San Francisco, CA.

Carver, A. D., Unger, D. R., \& Parks, C, L. (2004). Modeling energy savings from urban shade trees: An assessment of the CITYgreen ${ }^{\circledR}$ energy conservation module. Environmental Management, 34, 650-655. https://doi.org/10.1007/s00267-002-7003-y

Chen, W. Y., \& Jim, C. Y. (2007). Assessment and valuation of the ecosystem services provided by urban forests. In M. M. Carreiro, Y. Song and J. Wu. Ecology, Planning and Management of Urban Forests: International Perspective Springer Series on Environmental Management.

Coulson, R. N., \& Tchakerian, M. D. (2010). Basic landscape ecology. Knowledge Engineering Laboratory Partners, Inc., College Station, TX.

Forman, R. T. T. (1995). Some general principles of landscape and regional ecology. Landscape Ecology, 10, 133-142. https://doi.org/10.1007/BF00133027

Frank, J., \& Zamm, M. (1994). Urban environmental education: Arbor, Michigan, School of Natural Resources EE toolbox --workshop resource. Ann Michigan.

and Environment, University of

Jim, C. Y., \& Chen, W. Y. (2009). Ecosystem services and valuation of urban forests in China. Cities, 26, 187-194. https://doi.org/10.1016/j.cities.2009.03.003

Krasney, M. E., \& Tidball, K. G. (2009). Community gardens as contexts for science, stewardship, and civic action learning. Cities and the Environment, 2(1). https://doi.org/10.15365/cate.2182009

Krasney, M. E., \& Tidball, K. G. (2010). Civic ecology: Linking social and ecological approaches in extension. Journal of Extension, 48(1), Article Number 1IAW1. https://doi.org/10.15365/cate.31112010

Krasney, M. E., \& Tidball, K. G. (2012). Civic ecology: a pathway for Earth Stewardship in cities. Frontiers in Ecology and the Environment, 10(5), 267-273. https://doi.org/10.1890/110230

Kulhavy, D. L. Endsley, G., Unger, D., Grisham, R., Gannon, M., G., \& Coble, D. (2017). Service learning for the Port Jefferson History and Nature Center: Senior capstone forestry course. Journal of Community Engagement and Higher Education, 9(2), 67-79.

Kulhavy, D. L., \& Unger, D. R. (2016). Service-learning and participation in a capstone spatial science course. Journal of Service Learning in Higher Education, 15(1), 1-13.

Kulhavy, D. L., Unger, D. R., \& I-Kuai Hung., I. (2018). Student led campus desire path evaluation using Pictometry ${ }^{\circledR}$ Neighborhood Imagery. Journal of Studies in Education, 8(4). https://doi.org/10.5296/jse.v8i4.13695

Kulhavy, D. L., Unger, D. R., Hung, I., \& Zhang, Y. (2016). Comparison of AR.Drone quadricopter video and the visual CTLA method for urban tree hazard rating. Journal of Forestry, 114, 517-523. https://doi.org/10.5849/jof.15-005

Kulhavy, D. L., Wu, D., Unger, D. R., Hung, I., \& Sun, J. (2014). Comparison of tree condition and value for city and parks and Stephen F. Austin State University in Nacogdoches, Texas, U.S. Arboriculture and Urban Forestry, 40, 165-172.

Longcore, T., Li, C., \& Wilson, J. P. (2004). Applicability of CITYgreen urban forest analysis software to a densely build urban neighborhood. Urban Geography, 25, 173-186. https://doi.org/10.2747/0272-3638.25.2.173 
McPheerson, E. G., Nowak, D., Heisler, G., Grammond, S., Souch, C., Gant, R., \& R. Rowntree. R. (1997). Quantifying urban forest, structure, function and value: The Chicago Urban Forest Climate Project. Urban Ecosystems, 1, 49-61. https://doi.org/10.1023/A:1014350822458

Nowak, D. J. (1994). Understanding the structure of urban forests. Journal of Forestry, 92, 36-41.

Nowak, D. J., \& Crane, D. E. (2002). Carbon sequestration by urban trees in the USA. Environmental Pollution, 116(3), 381-389. https://doi.org/10.1016/S0269-7491(01)00214-7

Nowak, D. J., Stein, S. M., Randler, P. B., Greenfield, E. J., Comas, S. J., Carr, M. A., \& Alig, R. J. (2010). Sustaining America's Urban Trees and Forests. USDA Forest Service, Northeastern Research Station, Gen. Tech. Rep. NRS-62, Newtown Square, Pennsylvania. 27 p. https://doi.org/10.2737/NRS-GTR-62

Rowntree, R. A., \& Nowak, D. J. (1991). Quantifying the role of urban forests in removing atmospheric carbon dioxide. Journal of Arboriculture, 17, 269-275.

Sanborn. (2014). Green Infrastructure Mapping, Land Use Planning for CITYgreen Programming. Sanborn Map Company, Inc., Colorado Springs, Colorado.

Shirk, J. L., H. L. Ballard, C. C. Wilderman, T. Phillips, A. Wiggins, R. Jordan, ... R. Bonney. (2012). Public participation in scientific research: a framework for deliberate design. Ecology and Society, 17(2), 29. https://doi.org/10.5751/ES-04705-170229

Tidball, K. G., \& Krasny, M. E. (2010). Urban environmental education from a social-ecological perspective: Conceptual framework for civic ecology education. Cities and the Environment, 3, Article 11. https://doi.org/10.15365/cate.31112010

Tidball, K. G., \& Krasny, M. E. (2007). From risk to resilience: What role for community greening and civic ecology in cities? In A. E. J. Wals (ed.). Social learning towards a more sustainable world. Wageningen Academic Press, Wagengingen, The Netherlands.

\section{Copyrights}

Copyright for this article is retained by the author(s), with first publication rights granted to the journal.

This is an open-access article distributed under the terms and conditions of the Creative Commons Attribution license (http://creativecommons.org/licenses/by/4.0/). 